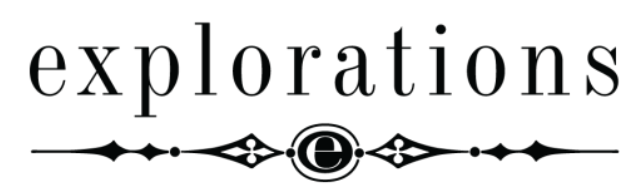

Explorations: A Journal of Language and Literature

\title{
The Double Bind of Patriarchy: (Im)possibility of Escape, Motherhood and Female Identity in Marilyn Duckworth's Rest for the Wicked
}

\author{
Anna Orzechowska (University of Warsaw) \\ DOI: $10.25167 / \mathrm{EXP} 13.17 .5 .6$
}

\begin{abstract}
The aim of this paper is to analyze the problem of escape from patriarchy in the context of motherhood and female identity as represented in Marilyn Duckworth's Rest for the Wicked. In her novel, the New Zealand writer exposes the ambiguous nature of patriarchy that renders departure from its schemas highly difficult and not as satisfactory as one may hope. On the one hand, patriarchy oppresses women by hampering their development of a distinct sense of self and appreciation of the potential of motherhood. On the other hand, it attracts them by guaranteeing stability. This gives rise to tension between a desire to subvert confining norms and a compulsion to satisfy social expectations. Duckworth does not exclude the possibility of change, but indicates its elusiveness. The writer shows that subversion requires the courage to face a world of uncertainty, a challenge that her heroine fails to meet.
\end{abstract}

Key words: Duckworth, Rest for the Wicked, patriarchy, motherhood, identity, escape

\section{INTRODUCTION}

In The Oxford Guide to Contemporary World Literature, Iain Sharp (1996) lists Marilyn Duckworth among the "most considerable fiction writers who emerged . . . in the late 1950s and early 1960s" (287) on the New Zealand literary scene. Her oeuvre, comprising mostly novels, but also short stories, poems, television and radio scripts, as well as a memoir, has won her a number of prestigious awards and distinctions, including the New Zealand Book Award for Fiction in 1985, the Order of the British Empire in 1987, and the New Zealand Prime Minister's Award for Literary Achievement in 2016. The last one, bestowed in recognition of Duckworth's lifetime contribution to New Zealand literature, may hopefully inspire renewed and more informed interest in her work, which has so far received scarce attention from scholars, including feminist critics. This neglect may be attributed to two major factors. For one thing, the writer's

Explorations: A Journal of Language and Literature, 5 (2017), pp. 61-72 
unwavering commitment to providing a genuine account of women's experiences and their struggle for identity in the face of social constraints has met opposition from "the continuing puritanism of her compatriots," as Heather Murray (1993) remarks in her tellingly entitled essay "Woman among the Puritans". For another, by displaying reluctance to align herself wholeheartedly with the feminist movement, ${ }^{1}$ as well as by addressing such taboo topics as female violence, ${ }^{2}$ the writer has failed to find favor with wider feminist circles.

Rest for the Wicked (publ. 1986), the third novel published after Duckworth's nearly fifteen-year-long hiatus from writing reflects the aforementioned tendencies. The writer portrays the troubled quest of a thirty-eight-year-old Jane, a housewife and mother to five children, for a distinct sense of self outside of patriarchal patterns. Duckworth, however, rejects blind confidence in the potential for change, emphasizing its elusiveness. To explore the problem, she uses the theme of escape, one that appears also in her earlier fiction, assuming various guises, be it that of a dreamlike descent into an unknown environment in Gap in the Spectrum (publ. 1959) or withdrawal into fantasy in an attempt to evade the pressures of daily life in Matchbox House (publ. 1963). In Rest for the Wicked, escape has both a spatial and a psychological dimension; Jane leaves home to participate in a project at the Sleep Research Centre, where she engages in an affair with a fellow patient, Allister, and plunges into the realm of dreams, gradually losing her hold on reality.

The aim of this paper is to analyze Jane's escape in the context of her experience of motherhood and unstable sense of identity. The first part discusses the heroine's motives, which, though seemingly crystal clear, prove nebulous and self-contradictory on closer inspection. The second part examines the Sleep Research Centre as a space of entrapment and investigates the significance of the woman's stay there. The final part focuses on the (im)possibility of escape from disempowering patriarchal demands as represented in the novel. The overarching argument of the paper is that, in Rest for the Wicked, the escape from patriarchal patterns attempted by Jane is only illusory because, being pervasive and internalized by the woman, they continue to be a looming presence in her life. More than that, despite oppressiveness, these patterns attract the heroine, as they constitute a safe framework in a world of uncertainty. To address the aforementioned problems, the present analysis draws on the theories of Simone de Beauvoir, Michel Foucault, Betty Friedan and Adrienne Rich regarding motherhood, female identity and freedom.

\section{ESCAPE OR NO ESCAPE? THAT IS THE QUESTION}

At the manifest level, the protagonist of Rest for the Wicked is driven by a desire for respite from the daily drudgery of attending to the needs of her children and husband. Although her family life is by no means fraught with any considerable hardships, she still

\footnotetext{
1 In her Janet Frame Memorial Lecture, Duckworth (2012) admits that, much as she supports women's liberation, a strong identification with the feminist agenda would be limiting: "Labels and pigeonholes had always bothered me. Feminism was another one of these . . What I wrote in my fiction was always a way of displaying feminist striving; . . . But that didn't mean I would carry a flag to say so."

${ }^{2}$ In an interview with Elizabeth Knox, Duckworth mentions that Seeing Red was excluded from the Top 20 of the Women's Book Festival due to its focus on female violence (Stratford 2011).
} 
feels oppressed in the role of mother and wife, associating it primarily with the performance of onerous duties. The feeling of entrapment in domestic obligations is so firmly rooted that it plagues Jane also during her stay at the Sleep Research Centre. When the heroine reads a reproachful letter from her husband about problems with their children, "the phrases coil about her like serpents, fill her mouth and gag her" (Duckworth 1986, 78). Her agitation testifies to the tremendous power wielded over Jane by the man; his mere words harass her from afar. Their oppressiveness is conveyed by the meaningful image of a snake, which recurs both in the heroine's dreams and wakefulness, each time eliciting an overpowering sense of horror on her part. One may interpret it in a Freudian vein as a phallic symbol and view the woman's response to it as a fear of patriarchal power, ${ }^{3}$ which continues to hold Jane in a tight grip, irrespective of her location.

It is patriarchal norms that determine the heroine's motherhood, leaving little room for authenticity. In this respect, the representation of Jane as a mother resonates with the distinction elaborated by Rich (1995) in her seminal study Of Woman Born between motherhood as experience and as institution understood respectively as "the potential relationship of any woman to her powers of reproduction and to children; and the institution, which aims at ensuring that the potential - and all women - remain under male control" (13; emphasis in the original). In contradistinction to the former, whose essence lies in the personal approach of a woman to the role of mother, the latter is predicated on demands and rules intended to inhibit the subversion of social dynamics. Accordingly, only some patterns of behavior can be recognized as acceptable, while others become stigmatized (Rich 1995, 14); for instance, maternal love should be "selfless" and "unconditional" (Rich 1995, 22), in the same measure as it is to be untainted by any negative emotions towards children (Rich 1995, 46). Most importantly, by no means does the feminist critic see motherhood as inherently oppressive; what she argues is only that its empowering potential cannot be unlocked due to the constraints of patriarchal society. The roots of this approach may be actually traced back to de Beauvoir. Although widely criticized for her hostility towards motherhood, de Beauvoir (1968) herself explained more than a decade after the publication of The Second Sex that she "simply asked that women experience them [maternal instinct and love] truthfully and fully" (201) instead of slavishly subscribing to patriarchal rules. As Penelope Deutscher (2008) claims, it is primarily the "devotion to habit and repetition" (102) usually involved in motherhood that the French feminist writer denounces because it precludes women from achieving transcendence.

Jane can be viewed as an embodiment of a woman enslaved by institutionalized motherhood and its repetitive patterns of behavior. The heroine's preoccupation with the proper fulfillment of her maternal obligations goes to such extremes that, when leaving her children alone for a moment to satisfy her own needs, ${ }^{4}$ she is afraid of being "caught . . . in the act of escaping their demands" (Duckworth 1986, 157). It is interesting to note that she often imagines her children as animals, the nurturing of whom constitutes the

\footnotetext{
${ }^{3}$ In A General Introduction to Psychoanalysis, Freud $(1958,163)$ lists snakes along with reptiles and fish among "male-sex symbols." Similarly, in The Interpretation of Dreams, Freud $(2010,370)$ underscores the significance of snakes as the "most important symbols of the male organ."

${ }^{4}$ The account of Jane's stay at the Sleep Research Centre and the subsequent events intersperses with flashbacks providing an insight into her domestic life.
} 
primary goal of her life. The role of mother becomes deprived for her of any personal stamp and reduced to mere instinct, as "institutionalized motherhood demands of woman maternal instinct rather than intelligence" (Rich 1995, 42). By the same token, it is also devoid of any social prestige, the most striking proof of which is the fact that Jane envies her friend Gaby the modicum of power that she has as a nun in contrast to her: ". . . she has God and the nun's habit to back up her authority. She has a still youthful body, uninvaded by man or child" (Duckworth 1986, 78). Motherhood, as de Beauvoir (1956, 88) would have it, "[imprison] her in repetition and immanence." It "[produces] nothing new" and limits her existence to a never-ending circle of mundane undertakings that, for all their utility, do not provide any creative contribution to humankind. Consequently, the woman can hardly use her role as a tool of empowerment.

This situation may be partly blamed on Jane herself. The heroine becomes complicit in perpetuating the patriarchal ideology by conforming to the established model of mothering, as she herself realizes: "It's her own fault. She has surrounded herself with children whose love and dependence tear her to shreds every day of her life" (Duckworth 1986, 12). Her behavior echoes the mechanism of self-surveillance described by Foucault. Having internalized social norms, Jane engages in self- disciplinary practices, accompanied by a sense of "permanent visibility" (Foucault 1977, 201). The heroine seems to act as the "obedient subject, the individual subjected to habits, rules, orders, an authority that is exercised around . . . and which [she] must allow to function automatically in [her]" (Foucault 1977, 128-129), as illustrated by the following dialogue with her husband:

'I shouldn't go out'

'Whyever not? I expect Jenny said that?'

'Cathy was crying.'

'You can't be expected to stay around and catch every tear'

'Yes, I can. I am expected' (Duckworth 1986, 85; emphasis in the original)

The heroine feels guilty about neglecting her daughter although Miles does not exert any pressure on her. As if constantly aware of the existence of an invisible disciplinary power, she coerces herself into meeting social expectations without any external compulsion, thereby acting as the perpetrator of her own oppression.

Apart from breeding frustration, institutionalized motherhood implies for Jane also selflessness, not only in the sense invoked by Rich, that is sacrificing one's needs for the sake of others, but also a literal one: a loss of a distinct and integral sense of self. In The Second Sex, de Beauvoir $(1956,460)$ remarks that housewives tend to perceive themselves as "being really nothing." Using a vivid metaphor, Jane admits in a similar vein that motherhood is tantamount to the gradual surrender of self: "cutting slices off herself to feed into the mouths of her young" (Duckworth 1986, 127). Wholly dedicated to the role of wife and mother, the heroine loses the boundaries between herself and her family. Jane's bond with one of her daughters is so uncannily close that their bodies seem to merge: "Julia's finger is dented and slightly torn. She bellows into her mother's stomach, gasping for breath. Jane feels the child's lungs vibrating in her womb. She is churned by this agony so like her own" (Duckworth 1986, 91). According to Friedan (1974), this is a common mechanism among housewives to compensate for their failure to develop a sense of subjectivity: "The greater her own infantilism, and the weaker her 
core of self, ... . the more exclusively will she live through her husband and children" (279). Importantly, she notes that such blurring of the self-other boundaries result in the weakening of a woman's "links to the world of reality" (Friedan 1974, 279). Accordingly, Jane's lack of mastery over her own experience is reflected in the narrative structure, marked by a disturbed temporal linearity, where the present mixes with the heroine's past at home, and obscure boundaries between reality and dreams, as signalized in the very beginning with an allusion to Alice in Wonderland: "Begin at the beginning and go to the end. Why isn't it like that? They promised her it would be like that. They put books in her hand which went like that. . . . Present, past, future. She tries - God knows she tries - to keep them in the right order. . . But they start to swing like flying trapezes, passing her from one to the other and back" (Duckworth 1986, 7).

The heroine's unease indeed evokes the "problem that has no name" scrutinized by Friedan (1974, 11) in Feminine Mystique: the sense of emptiness that arises from devoting one's whole life to the role of housewife. Friedan remarks that the American women of the 1950s and 1960s, frustrated with the monotony of their existence, would often find fault with themselves: "Other women were satisfied with their lives, she thought. What kind of woman was she if she did not feel this mysterious fulfilment waxing the kitchen floor?" (Friedan 1974, 14). Similarly, Jane blames herself for her own inability to derive self-satisfaction from her roles: "Other women were content. Why not her?" (Duckworth 1986, 154). For all her adherence to patriarchal norms, however, the heroine does not want to have her identity subsumed under motherhood. When she sees that people start their acquaintance with her by asking about her children, "it strikes her as odd that the number and ages of her children should be considered the most interesting aspect of her identity" (Duckworth 1986, 30). The only way out of this predicament is to forge a sense of self independence from her social functions: "I want to feel special to myself" (Duckworth 1986, 78). Consequently, the heroine's escape assumes the dimension of a quest for subjectivity, to which she admits while describing Allister as "another neurotic like herself seeking identity" (Duckworth 1986, 36).

It has been argued so far that Jane is motivated primarily by her willingness to escape the straitjacket of social demands and to construct a stable sense of self. When examined more closely, however, her intentions may seem more complex and ambiguous. Most importantly, it seems that the heroine herself is not fully aware of their true nature: "Is this why she has come? To fit herself into a comfortable niche? Of course, not. She has come to get away from restricting enclosures. From the arms and voices of her children, the routine of housework, the watchful eye of her conscience" (Duckworth 1986, 33). The foregoing passage suggests that, although the woman strives to dispel such a thought, her escape may be prompted, at least at the unconscious level, by a desire to adapt herself better to social norms.

First and foremost, what may strike one as telling is the place that Jane chooses to escape to. By no means does the Sleep Research Centre appear to be a space where one may find relief from the pressures of life. It may offer the possibility to avoid daily chores, yet it is a hospital-like place of confinement, whose inmates are subject to constant control and have to submit themselves to its order by scrupulously recording their dreams or undergoing medical procedures. Interestingly, Jane remarks that "dreams under controlled conditions [at the centre] are likely to be more confined and mundane than dreams in the freedom of one's own home" (Duckworth 1986, 7), which suggests that, rather than being offered leeway to indulge in guilty desires, the patients are induced 
to eliminate any longings that stand in contradiction to social norms. While the Sleep Research Centre will be analyzed at greater length in the subsequent section, for now it should be stated that Jane clearly flees from one place of "restricting enclosures" (Duckworth 1986, 33) to another one, a fact that casts serious doubt as to the liberating nature of her act.

Significantly, also the heroine reveals that one of her goals in entering the centre is to be cured from madness: "She prefers to offer her subconscious mind to Lenard rather than a mental institution ... . she is the only one who knows she is mad" (Duckworth 1986, 12). Her alleged madness may be construed as non-compliance with the accepted social norms. It is only the heroine who knows about it because no one else realizes that, under the guise of a perfect housewife and a loving mother, who "finds her chief gratification in taking care of her children," as should be natural for mothers in patriarchal society (Rich 1995, 22), she hides an overwhelming sense of ennui. Having internalized patriarchal values, the woman is unable to explain her own dissatisfaction with what would bring happiness to other women in any other way than by insanity. It is possible that she unconsciously struggles to better fulfill social expectations in order to regain internal stability.

\section{THE VICIOUS CIRCLE OF ENTRAPMENTS}

As already mentioned, contrary to Jane's hopes, the Sleep Research Centre essentially offers her only another form of oppression. The establishment proves a sinister place marked by an undercurrent of entrapment, created to a large extent by the people that the heroine meets there. Of paramount importance in this respect is Lenard, the supervisor of the research project, who appears to be a quintessentially patriarchal figure in his inclination to wield control over others. One of his peculiarities is a tendency to employ women who either are "tongue-tied with men" (Duckworth 1986, 70) or literally do not speak, such as one of the nurses, Una. Lenard's curious dislike of "talkers" (Duckworth 1986, 70) exposes the imbalanced power relations between him and women: while he has the authority to set the rules, they are deprived of any voice. Importantly, Una's dumbness "fills Jane with a kind of choked horror - how crippling to have no tongue with which to cry for help" (Duckworth 1986, 70), a fact suggesting that speechlessness indeed figures in the novel as a symbol of women's disempowerment. Furthermore, Lenard's interest "in dreams, in disembodied minds, in ideas for themselves" (Duckworth 1986, 9) testifies to his proclivities for manipulation. It is suggested also that his seemingly innocuous interests may be a smokescreen for a morbid fascination with death when Allister warns Jane that the man is killing the patients to conduct post-death experience research, a threat that forces the heroine to undertake another escape.

The sense of discomfort is magnified by the ominous figure of the hooded-eyed $\mathrm{Mr}$. Morpeth, who elicits horror from Jane although he is seemingly nothing more than a nosy and obscene man. At the symbolic level, however, considering that he is persistently compared to a reptile or a snake - both potent phallic symbols according to Freud, as already mentioned - Mr. Morpeth can also be viewed as an epitome of male power and unsurpassable presence of patriarchy in Jane's life: "She feels his hand as though it were the snake, as if the snake were transmitted like an electric current from his body to hers" (Duckworth 1986, 20). That he is more of a symbol than a real presence can be inferred 
from the following confession made by the heroine: "It isn't so much his actual appearance, it's the feeling I get when I look at him. This person, or thing, I used to dream about was somehow deformed and slow-moving but he always managed to be where I least wanted him to be. . . . I dreamt him around early puberty. Sometimes he took the form of a large slug that walked upright" (Duckworth 1986, 21). What is of crucial importance in the quoted account, apart from the visible phallic imagery, is the fact that a figure similar to Morpeth appeared in Jane's dreams even before she met the man in reality. This may suggest that he actually represents her subconscious fears about the menace posed by the power of phallus, especially considering that the dreams started during the period of sexual awakening.

At the Sleep Research Centre, Morpeth appears in Jane's dreams as a person who threatens her with sexual advances and physical violence. Also, Jane is constantly accompanied by an uneasy feeling that the man lurks somewhere near. He indeed tracks her and Allister when they indulge in an illicit affair. During their trip to a forest, "behind them they are uneasily aware of Mr. Morpeth following" (Duckworth 1986, 19). Later in the novel, the man reveals his voyeuristic inclinations, watching the couple have sex, a characteristic that reinforces his status as a symbol of omnipresent social surveillance, which does not allow Jane to realize her guilty desires without anxiety. Instead of finding rest, the heroine is thus subjected to more control than she had probably ever experienced at home.

The Sleep Research Centre proves equally unfit to function as a place where Jane could find her wished-for sense of identity. Quite the contrary, her selfhood becomes destabilized to an even greater extent as the boundaries between subject and object are no longer clear-cut, with patients being treated as guinea pigs on a par with animals and plants. Jane experiences far-reaching self-alienation, having problems to differentiate herself from non-humans: "Jane isn't a white rat or a white rose, although in dreams she has moments of confusion about this" (Duckworth 1986, 12). The loss of subjectivity comes to light also in the curious tendency to compare herself to vegetables or animals, which reflects the disempowering and dehumanizing character of the place. It is also important to once again pay attention to the issue of shapelessness and shape. The laboratory is repeatedly contrasted with Jane's home as a space associated with shape. Its shape, however, seems far from bringing any opportunity to achieve a sense of subjectivity; it signifies rather entrapment as Jane becomes haunted by recurring claustrophobic dreams about doors leading to other doors without any point of exit.

Most importantly, at the Sleep Research Centre, it transpires that patriarchal norms have been internalized by Jane too deeply to be easily eradicated. Even when the heroine violates them, they continue flooding back in dreams and voices, giving rise to a sense of guilt. This proves that, as Helen Cixous $(1981,14)$ argues, "the unconscious is always cultural and when it talks it tells you your old stories": the patriarchal schemas invade the innermost sphere of the mind, hence their insidiousness. Consequently, the heroine is unable to escape from the role of caregiver, as evidenced by a dream in which she tries to protect her family against an earthquake: "She is very pleased with herself for being in the right spot at the right time" (Duckworth 1986, 15). Jane's obsession about the proper performance of her role assumes almost paranoiac dimensions when she mistakes tree branches for her children and convinces herself in despair that "they can't expect her to feel maternal towards a tree, can they" (Duckworth 1986, 15). Significantly, this is another episode exposing the aforementioned Foucaltian mechanism of self-surveillance. 
Even when not directly controlled by any external force, she displays cautiousness not to overstep the norms.

Although for some time "she doesn't dream about her children so often" (Duckworth $1986,49)$, the pressure of social expectations comes to an even greater prominence on a tour around Europe with Allister. The patriarchal patterns that she wants to evade prove pervasive and thus always intrude upon her life. Seeing women with children all around, Jane grows so anxious about abandoning her own family that she starts to have hallucinations, gradually losing the ability to differentiate between reality and fantasy; she imagines other children calling her mother and believes to hear their accusatory voices. Moreover, her affair proves to be yet another disappointment when the woman realizes that Allister is entangled in various social commitments: "She had believed Allister to be a person alone in the world. A stranger in every sense, with who she could safely indulge her baser instincts. . . . Suddenly Allister is too real" (Duckworth 1986, 146). What attracted her to the man at the Sleep Research Centre was the fact that he seemed unfettered by any social constraints. When the lover proposes marriage, she comes to a realization that may be summarized quoting an excerpt from The Second Sex: "If a liaison becomes stabilized, it often takes on a familiar, conjugal character in the end; there will again be found in it all the vices of marriage: ennui, jealousy, calculation, deception, and the like" (de Beauvoir 1956, 526). In other words, Jane dreads stepping into the very same oppressive strictures that she is escaping from. At the same time, paradoxically, the mere idea that she could deviate from social norms in such a blatant way magnifies her anxiety so that Jane strives to strangle Allister - probably only in her vision - in an attempt to silence the subversive voice: "I hate you. You don't listen! You keep telling me what I need! You don't know anything about what I need" (Duckworth 1986, 159). The second escape thus proves equally unsuccessful as the first one. Having once again failed to achieve freedom, the heroine decides to go back to England.

\section{4. (IM)POSSIBILITY OF ESCAPE}

Duckworth presents a vicious circle of escapes, none of which enables the heroine to surmount the patriarchal constraints or to forge a sense of identity. As the plot unfolds, it transpires that escape is beyond her reach. Jane finally decides to return to the Sleep Research Centre and, on a train on her way back to England, realizes that there is "no rest for the wicked" (Duckworth 1986, 164). Thereby the novel reneges on the promise of subversion made in its title, playfully alluding to a common saying originating from the Bible. It may be concluded that Jane's experiences correspond to the pattern indicated by Heidi Slettedahl Macpherson $(2000,235)$ based on her analysis of the theme of escape in North American feminist fiction: "Within the boundaries of feminist fiction, escape can be attempted, enacted, celebrated - but never finally or safely contained."

This does not imply, however, that Duckworth regards all such attempts as inherently futile and unfeasible. Neither does the writer portray the heroine as deprived of free will and any possibility of change whatsoever. Importantly, the heroine herself believes that "our lives are not prefabricated" (Duckworth 1986, 7), rejecting a deterministic view on human life. The message presented in the novel rather strikes a chord with the thought of de Beauvoir, a parallel that seems especially legitimate in view of the fact that Duckworth 
confirms the presence of existentialist undertones in her fiction (Benson 1998, 133). De Beauvoir $(1956,78)$ sees women as both inherently free and limited by external circumstances: "For us woman is defined as a human being in quest of values in a world of values, a world of which it is indispensable to know the economic and social structure." On the one hand, oppression comes from patriarchal society; on the other hand, women themselves become the agents of their own undoing by readily accepting patriarchal patterns for fear of facing the implications of their existential freedom:

To decline to be the Other, to refuse to be a party to the deal - this would be for women to renounce all the advantages conferred upon them by their alliance with the superior caste. Man-the-sovereign will provide woman-the-liege with material protection and will undertake the moral justification of her existence; thus she can evade at once both economic risk and the metaphysical risk of a liberty in which ends and aims must be contrived without assistance. Indeed, along with the ethical urge of each individual to affirm his subjective existence, there is also the temptation to forgo liberty and become a thing. This is an inauspicious road, for he who takes it - passive, lost, ruined - becomes henceforth the creature of another's will, frustrated in his transcendence and deprived of every value. But it is an easy road; on it one avoids the strain involved in undertaking an authentic existence (de Beauvoir 1956, 20).

According to de Beauvoir, escape from oppressive patriarchal values is achievable and even indispensable in ethical terms, yet it requires women to reject self-complacency and carry the burden of shaping their life, an effort that may appear too heavy.

Echoes of this approach resonate in the following passage from Rest for the Wicked:

In the dream, she is being held . . by an invisible force. The force may be overcome with will-power but does she have enough? She struggles. The force is at once magnetic and pressing, depending on which way she moves. One moment it resists her limbs like a solid wall of water, the next moment tugs at her ankles like heavy jelly. ... It is pulling her back so that she falters, hesitates and leans as if she is listening (Duckworth 1986, 93)

The power of patriarchy may be subverted through the woman's efforts. The possibilities of change, however, are by no means within easy reach because patriarchal schemas hold an attraction for women despite their oppressiveness. Jane fails to succeed in her struggle not only because patriarchal norms are pervasive and invasive, but also because they provide her with ready-made solutions. In Ethics of Ambiguity, de Beauvoir (1948) distinguishes different methods of avoiding one's freedom, one of them consisting in a refusal to acknowledge that freedom is achievable at all and the resultant acceptance of external values: "The serious man's dishonesty issues from his being obliged to ceaselessly renew the denial of this freedom. He chooses to live in an infantile world, but to the child the values are really given" (47). She ascribes this type of bad faith to women, whom she charges with rejecting freedom out of moral indolence: "There is often laziness and timidity in their resignation; their honesty is not quite complete; but to the extent that it exists, their freedom remains available, it is not denied" (de Beauvoir 1948, 48). Similarly, in Feminine Mystique, Friedan (1974, 68) poses a provoking question: "What if those who choose the path of 'feminine adjustment'. . . are simply 
refusing to grow up, to face the question of their own identity." Later she states explicitly that women's readiness to forgo all opportunities indeed constitutes a flight from anxieties inherent in identity formation: "The freedom to lead and plan your own life is frightening if you have never faced it before. It is frightening when a woman finally realizes that there is no answer to the question 'who am I' except the voice inside herself" (Friedan 1974, 326). In the light of the two aforementioned texts, it seems justified to construe Jane's behavior as resulting from the fear of the "existential void in which [she] haplessly floats" outside of patriarchy, as other characters in Duckworth's novels do (Murray 1993). The role of housewife protects her from the toils of life in a world where "nothing stays the same, the boundaries continually shift" (Murray 1993).

Jane's ambiguous approach towards subversion is encapsulated by the previously mentioned symbol of closed doors: "She pulls at the door to get away. It won't open. She tugs harder on the chrome handle, beginning to sweat. . . The door opens suddenly outward and she almost falls into the passageway. She shakes with hysterical laughter" (Duckworth 1986, 79). In Rest for the Wicked, doors symbolize entrapment in oppressive norms - most notably, another female character commits suicide behind locked bathroom doors - yet their opening throws Jane violently into a space that arouses fear and bafflement. Afraid of entrapment as she is, freedom proves not less forbidding. Jane thus vacillates between self-determination and enclosure in social norms; she grows alienated both from her social roles and the world at large, which becomes "a cesspool of human survival," as the Sleep Research Centre (Duckworth 1986, 7). Finally, an absolute freedom proves too great a burden; the heroine searches for something to build her life upon, even at the price of oppression. She treats the role of mother as a means of avoiding responsibility for her own life and the anguish of existence, a course of action deplored by de Beauvoir (1968, 201): "they [women] often use them [maternal instinct and love] as excuses and take refuge in them, only to find themselves imprisoned in that refuge when those emotions have dried up in their hearts." Her choices illustrate also the point made by Anne Dally $(1982,231)$ in Inventing Motherhood that "motherhood is often used by mothers themselves as an escape from the threatening modern world which they feel they cannot face."

\section{CONCLUSIONS}

Throughout her career, Marilyn Duckworth has avoided easy categorizations and unequivocal solutions, thereby often distancing herself from mainstream feminists. In Rest for the Wicked, she brings to light the ambiguous nature of patriarchy, which renders escape outside its patterns highly problematic and not necessarily as liberating as women hope it to be. On the one hand, the writer demonstrates the oppressive influence of patriarchal norms on Jane's life: they hamper the woman in appreciating the potential of motherhood and developing a distinct sense of identity. On the other hand, they attract her by guaranteeing stability and safety. Patriarchy traps the heroine in a double bind, giving rise to tension between the desire to subvert confining norms and the compulsion to satisfy social expectations. The attempted escapes ultimately imply only a change of environment as patriarchal schemas continue to permeate Jane's life, visible in the external world and ingrained in her mind. Most importantly, the heroine lacks the courage and self-will necessary to take responsibility for her own life and challenge a 
world of uncertainty. All in all, in her case, any solution leads to dissatisfaction; as the last words of the novel go, there is "no key" (Duckworth 1986, 166).

\section{REFERENCES}

de Beauvoir, Simone. 1948. The Ethics of Ambiguity. Translated by Bernard Frechtman. New York: Philosophical Library.

de Beauvoir, Simone. 1956. Second Sex. Translated by H. M. Parshley. London: Jonathan Cape.

de Beauvoir, Simone. 1968. Force of Circumstance. Translated by Richard Howard. Harmondsworth: Penguin.

Benson, Dale. 1998. "Marylin Duckworth: When Existentialism Was in the Air." Journal of New Zealand Literature (JNZL) 16:133-146. Accessed January 20, 2017. http://www.jstor.org/stable/20112300.

Cixous, Helen. 1981. "Castration or Decapitation." Translated by Annette Kuhn. Signs 7.1: 41-55. Accessed January 20, 2017. http://www.jstor.org/stable/3173505.

Dally, Anne. 1982. Inventing Motherhood: The Consequences of an Ideal. London: Burnett Books.

Deutscher, Penelope. 2008. The Philosophy of Simone de Beauvoir: Ambiguity, Conversion, Resistance. New York: Cambridge University Press.

Duckworth, Marilyn. 1986. Rest for the Wicked. Auckland: Hodder and Stoughton.

Duckworth, Marilyn. 2012. "Learning to Swivel: The Changing Face of New Zealand Literature." Janet Frame Memorial Lecture delivered during the New Zealand Book Month, Te Papa Tongarewa, 1 March.

Foucault, Michel. 1977. Discipline and Punish: The Birth of the Prison. London: Allen Lane.

Freud, Sigmund. A General Introduction to Psychoanalysis. 1958. Translated by Joan Riviere. New York: Permabooks.

Freud, Sigmund. 2010. The Interpretation of Dreams: The Complete and Definitive Text. Translated by James Strachey. New York: Basic Books.

Friedan, Betty. 1974. Feminine Mystique. New York: Dell Publishing Company.

Murray, Heather. 1993. "Women Among the Puritans." New Zealand Books: A Quarterly Review 10. Accessed January 20, 2017. http://nzbooks.org.nz/1994/literature/womenamong-the-puritans-heather-murray.

Rich, Adrienne. 1995. Of Woman Born: Motherhood as Experience and Institution. New York: W.W. Norton.

Sharp, Iain. 1996. "New Zealand." In The Oxford Guide to Contemporary World Literature, edited by John Sturrock, 284-300. Oxford: Oxford University Press.

Slettedahl Macpherson, Heidi. 2000. Women's Movement: Escape as Transgression in North American Feminist Fiction. Amsterdam: Rodopi.

Stratford, Stephen. 2011. "Elizabeth Knox on Marilyn Duckworth." Quote Unquote Blog, December 27. http://quoteunquotenz.blogspot.com/2011/12/elizabeth-knox-onmarilyn-duckworth.html. 
This work is licensed under the Creative Commons Attribution 3.0 Unported License.

http://creativecommons.org/licenses/by/3.0/

AUTHOR'S BIO: Anna Orzechowska graduated from the Institute of English Studies at the University of Warsaw in 2016. She is a second-year PhD student in British Literature. Her research project concerns the formation of female identity in the fiction of Marilyn Duckworth. Her academic interests include New Zealand women literature, feminist studies, in particular feminist existentialism, and motherhood studies.

E-MAIL: anna.orzechowska(at)student.uw.edu.pl 